\title{
Developing a PCR assay to detect Aspergillus parasiticus
}

\author{
- Nguyen Huu Nhien \\ - Nguyen Thi Mai Tram \\ International University, VNU-HCM \\ - Nguyen Thi Hue \\ University of Science, VNU-HCM \\ (Received on November $24^{\text {th }} 2014$, accepted on June $19^{\text {th }} 2015$ )
}

\begin{abstract}
Aspergillus parasiticus is one of the producers of aflatoxins in food. They may produce aflatoxin $B$ and $G$ which can lead to serious diseases in human. Aflatoxin is known as a type of carcinogens. People ingesting infected food even in a very low level for a long time can get cancer because of aflatoxin accumulation. Detection of aflatoxin or aflatoxin producers in foods is necessary to improve the life quality by decreasing the risk of getting diseases. Recently, the contemporary method to detect A. parasiticus is a morphological method but it still retains many limitations. In this study, a PCR based method was developed to provide a basic for develop a new method to detect $A$. parasiticus in food that overcame the disadvantages of the conventional morphological method. A specific set of

primers was designed based on norB-cypA genes and successfully optimized for best amplification results at $62{ }^{\circ} \mathrm{C}$. The sensitivity of the test was identified to be $0.005 \mathrm{ng} / \mu \mathrm{L}$ of target fungi DNA. A DNA isolation protocol was also optimized to ensure the success of the PCR assay, using SDS lysis, sand and thermal shock. The protocol from DNA isolation to PCR was successfully developed and provided a useful tool to improve the diagnosis of aflatoxins at an early stage and control all stages of food production. The success of this study is designing a pair of primers and a PCR assay which is specific for detection of $A$. parasiticus among other aspergilus species. This PCR assay can be used in the future for further development a PCR method for detection of $A$. parasiticus in food.
\end{abstract}

Key words: Aspergillus parasiticus, aflatoxins, aflatoxin gene cluster, norB-cypA, $P C R$

\section{INTRODUCTION}

Aspergillus species are among the most ubiquitously found mold fungi throughout the world which are of high importance in medicine, agriculture and biotechnology. Besides inducing direct pathogenesis, they also produce various types of toxic secondary metabolites, mycotoxins and cause non-contagious mycotoxicoses [1]. Out of all different types of mycotoxins, aflatoxins are the most potent natural carcinogens known, possessing hepatoxic and immunosuppressive properties which can cause acute liver damage, liver cirrhosis, tumor induction and teratogenesis [2]. They have been recognized as a possible human carcinogen by International Agency of Research on Cancer [3]. These mycotoxins are produced primarily by Aspergillus parasiticus and A. flavus which may invade agricultural products during plant growth, during harvest and 
finally in storage, resulting in significant economic losses [4].

A. parasiticus, unlike A. flavus which only produces aflatoxin $B$, may produce both aflatoxins B and G. Discrimination between these two species and distinguishing them from closely related species is difficult when using conventional methods, which are mainly based on morphological or immunological features including culturing the fungus in suitable inducing media, extracting aflatoxins with other solvents, and monitoring their presence by chromatographic and ELISA techniques [5, 6]. These methods are time-consuming and require considerable performing expertise, which are their major drawbacks. Furthermore, the complexity in the presence of aflatoxinogenic and non-aflatoxinogenic Aspergillus species can cause false negative results in detection $[7,8]$.

The application of DNA-based techniques, particularly polymerase chain reaction (PCR), permits rapid, sensitive and specific detection that overcomes the disadvantages of conventional method, necessary to devise strategies to control and reduce fungal mass and toxin production at early and critical stages of the food chain. Up to date, there have been few studies on detection of A. parasiticus using molecular methods. RT-PCR with target genes aflD, aflO, aflP [9], PCR-RFLP with target gene aflR, multiplex-PCR with target genes nor-1, ver-1, omt-1 and apa-2 [10], realtime PCR with primers and probe designed on multicopy ITS2 rDNA target sequence have been used [11]. However, these methods were established to detect both A. parasiticus and A. flavus with the aim of monitoring aflatoxinproducing Aspergillus contamination of food and feedstuffs. A recent study on detection of only $A$. parasiticus using real-time PCR assay was performed by Sardinas N. in 2010 [11, 12] with primers designed on the multicopy internal transcribed region of the rDNA unit (ITS1-5.8S-
ITS2 rDNA). This study was successful in accurately detecting and quantifying $A$. parasiticus at spore concentrations equal or higher than $10^{6}$ spores/g. Nevertheless, this method needs to be performed in expensively equipped laboratories, which may increase the detection cost when applied in practice.

In this study, a cheap, accurate, sensitive and specific PCR assay is developed to detect $A$. parasiticus. The specificity of the assay was considerably improved when norB-cypA genes were used. These genes, which belong to the aflatoxin gene cluster, were shown to involve in biosynthesis of aflatoxins G [13-15]. Furthermore, they are highly variable among closely related species in Aspergillus genus, allowing successful detection of $A$. parasiticus. The possibility of this method will provide further information to develop a new method to predict mycotoxins profiles as well as to detect aflatoxin-producing species in food quality assurance labs in the future.

\section{MATERIALS AND METHODS}

\section{Fungal isolates and culture conditions}

Two different genera of filamentous fungi were used in this study (Table 1), including five Aspergillus species and one Penicillium species. Fungal strains were obtained from different Culture Collections in Vietnam or isolated from food. Morphological and genetic variations of $A$. parasiticus among intraspecies and extraspecies would be the important points to identify this species. Among these, both A. parasiticus and $A$. flavus belong to an important group of foodborne fungi which can produce aflatoxins. A. oryzae and $A$. niger are two fermented fungi which are "generally regarded as safe" (GRAS) by the FDA [16]; while A. candidus acts as a human pathogen causing invasive infection[17]. Finally, $P$. aethiopicum is an Aspergillus-related species. [18].

\section{Trang 44}


The isolates were maintained by regular subculturing on slant tubes containing Potato Dextrose Agar (PDA) (Merck, Germany) at $25{ }^{\circ} \mathrm{C}$ in the dark for 48 to 72 hours and then stored as spore suspension in sterile paraffin oil at $4^{\circ} \mathrm{C}$. Fungal strains were cultured for DNA extraction in Erlenmeyer flasks containing $50 \mathrm{~mL}$ of Malt Extract (ME) broth (Himedia, India) and incubated at $25{ }^{\circ} \mathrm{C}$ in an orbital shaker (120 rpm) for 48 to 72 hours. Mycelial mass was filtered through a filter paper, washed 3 times with $\mathrm{NaCl}$ $0.8 \mathrm{M}$ and kept at $-20{ }^{\circ} \mathrm{C}$ until DNA extraction.

Table 1. List of selected Aspergillus species and Aspergillus-related species

\begin{tabular}{lll}
\hline Species name & $\begin{array}{l}\text { Accession } \\
\text { number }\end{array}$ & Provider \\
\hline Aspergillus parasiticus & VTCC-F-1130 & VTCC-F-1132 \\
& VTCC-F-1159 & $\begin{array}{l}\text { Vietnam Type Culture } \\
\text { Collection }\end{array}$ \\
& VTCC-F-160 & $\begin{array}{l}\text { Vietnam Type Culture } \\
\text { Collection } \\
\text { Vietnam Type Culture } \\
\text { Aspergillus flavus }\end{array}$ \\
& VTCC-F-898 & $\begin{array}{l}\text { Collection } \\
\text { Pasteur Institute HCM city } \\
\text { Asolated from maize - } \\
\text { Quatest3 }\end{array}$ \\
\hline Aspergillus oryzae & VTCC-F-910 & $\begin{array}{l}\text { Vietnam Type Culture } \\
\text { Collection }\end{array}$ \\
\hline Aspergillus niger & VTCC-F-912 & $\begin{array}{l}\text { American Type Culture } \\
\text { Collection }\end{array}$ \\
\hline Aspergillus candidus & ATCC-16404 & Isolated from food - Quatest3 \\
\hline Penicillium aethiopicum & TNTT & Quatest3 \\
\hline
\end{tabular}

\section{DNA extraction}

DNA was extracted from mycelium following SDS method which was modified from Plaza's method [19]. The yield of the method was independently evaluated in all species shown in table 2. DNA concentrations were determined using a NanoDrop® 2000c spectrophotometer (Nanodrop Technologies, Wilmington, USA). The purity of the extractions was between 1.8 and 2.0. The DNA of the samples was diluted to 100 $\mathrm{ng} / \mu \mathrm{L}$.

\section{PCR amplification}

The assays were performed in a Veriti® 96Well Fast Thermal Cycler (Applied Biosystems,
USA). Amplification reactions were carried out in volumes of $10 \mu \mathrm{L}$ containing $1.0 \mu \mathrm{L}(100 \mathrm{ng})$ of template DNA, $1.0 \mu \mathrm{l}$ of each primer $(10 \mu \mathrm{M})$, $2.0 \mu \mathrm{L}$ of $5 \mathrm{X}$ PCR buffer, $1.0 \mu \mathrm{L}$ of $\mathrm{MgCl}_{2}(25$ $\mathrm{mM}), 0.8 \mu \mathrm{L}$ of dNTPs $(10 \mathrm{mM})$ and $1.0 \mu \mathrm{L}$ of Taq DNA polymerase ( $5 \mathrm{U} / \mu \mathrm{L})$ (Promega, USA).

PCR assay was performed using the thermal cycle of 5 minutes at $95{ }^{\circ} \mathrm{C}$, then 35 cycles of 30 seconds at $95{ }^{\circ} \mathrm{C}, 30$ second at annealing temperature, 30 seconds at $72{ }^{\circ} \mathrm{C}$ and finally 3 min at $72{ }^{\circ} \mathrm{C}$. The annealing temperature was checked in the range of $58-66{ }^{\circ} \mathrm{C}$ to get the best annealing temperature for further analysis.

PCR product was then analyzed in $2 \%$ agarose ethidium bromide gel at $150 \mathrm{~V}$ in TBE $0.5 \mathrm{X}$ buffer for 30 minutes and observed under 
an ECX-20. M transilluminator (Vilber Lourmat, Germany).

\section{RESULTS}

\section{Primer design}

Primers were designed on the basis of sequence alignments of the norB-cypA genes, the farthest upstream portion of the aflatoxin biosynthesis gene cluster. This design, evaluated by Ehrlich [20, 21], was carried out on the completed sequence of aflatoxin pathway gene clusters of several strains from different origins, Aspergillus parasiticus, A. flavus $\mathrm{AF} 13$, A. flavus AF36, A. flavus AF70, A. flavus BN008R, A. oryzae RIB40, A. normius isolate AN13137 the information of which are available on NCBI website with GenBank accession numbers AY371490.1, AY510451.1, AY510455.1, AY510453.1, $\quad$ AY510452.1, AB196490.1, AY510454.1.

The primers APA1 $(5$ GGATTCGTGAGTGTCTTTAGGG 3') and
APA2 (5' GGTAAATGCTCCGCACAGTC 3') fulfilled the requirements of specificity and efficacy required for A. Parasiticus identification. The amplicon for this set of designed primers is $343 \mathrm{bp}$. This amplicon also be checked based on the GenBank and the result shown that it is specific.

Gradient temperature PCR was performed to evaluate the primers annealing temperature to the gene specific to A. paraciticus. The gradient temperature PCR was performed with the range of temperature of $56-66{ }^{\circ} \mathrm{C}$. The result showed that the target amplicon can be amplified easily at $56{ }^{\circ} \mathrm{C}, 58{ }^{\circ} \mathrm{C}, 60{ }^{\circ} \mathrm{C}, 62{ }^{\circ} \mathrm{C}$ and at $64{ }^{\circ} \mathrm{C}$ while at $66{ }^{\circ} \mathrm{C}$ there is no product for the PCR assay (Figure 1). To avoid extra-products at low temperature and lost of product at high temperature, $62{ }^{\circ} \mathrm{C}$ is selected at the best temperature for further experiments. Hence, the optimal temperature for the designed primer set was $62{ }^{\circ} \mathrm{C}$.

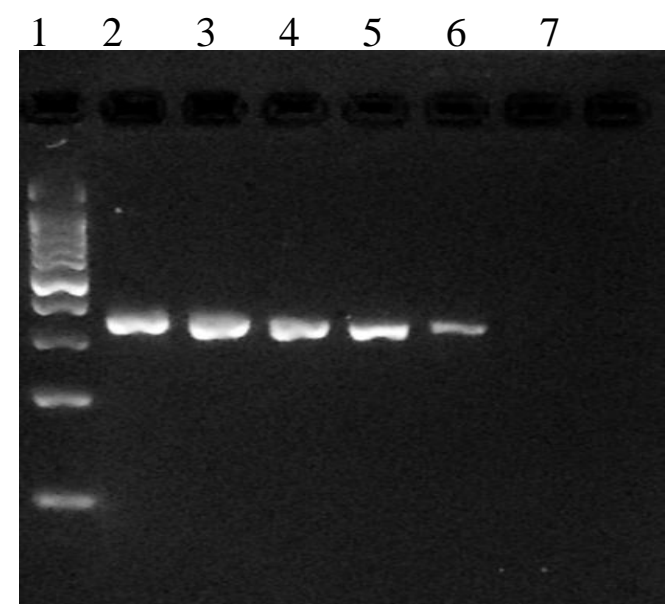

Figure 1. Optimizing annealing temperature for PCR assay amplifying the specific A. paraciticus target. Lane 1: $100 \mathrm{bp}$-DNA molecular weight ladder. Lane 2- 7: annealing temperature at $56{ }^{\circ} \mathrm{C}, 58{ }^{\circ} \mathrm{C}, 60{ }^{\circ} \mathrm{C}, 62{ }^{\circ} \mathrm{C}, 64{ }^{\circ} \mathrm{C}$ and 66 ${ }^{\mathrm{O}} \mathrm{C}$. The selected annealing temperature is at $62{ }^{\circ} \mathrm{C}$ (lane 5 ).

The amplicon after be amplified is confirmed by sequencing. The target amplicon is sequenced by ABI 3130 (Namkhoa Company). The result showed that the amplified amplicon is the expected target which designed based on Genbank (Figure 2).

\section{Trang 46}




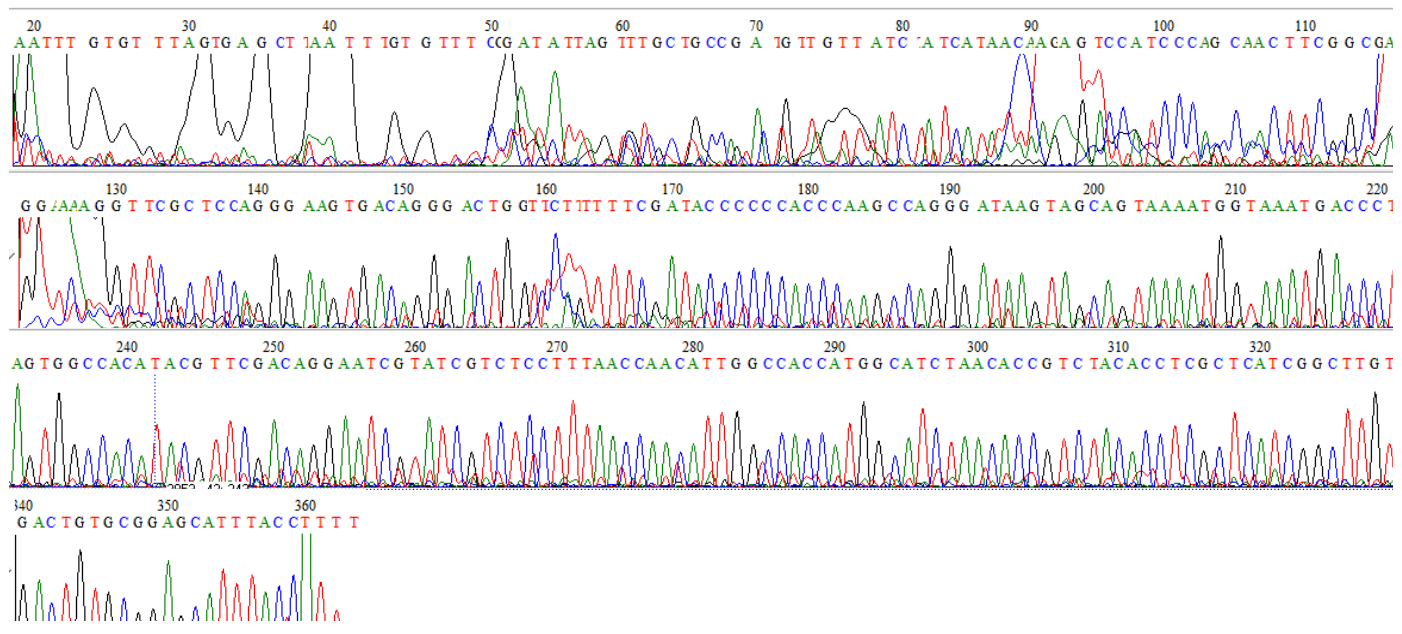

Figure 2. The DNA sequence of a specific A.paraciticus target of $343 \mathrm{bp}$.

\section{Specificity testing}

The specificity of the primer pairs APA1/APA2 for $A$. parasiticus was tested in PCR assays by using genomic DNA extracted from closely related species and genera that usually contaminate the same foods. The samples were prepared independently with DNA from individual strain at the concentration of 100 $\mathrm{ng} / \mu \mathrm{L}$. An additional sample containing DNA mixture of these molds with the same ratio in a concentration of $100 \mathrm{ng} / \mu \mathrm{L}$ was also used to test the capacity of the assay in detection of
A. parasiticus contaminated with other species

The results shown in Figure 3 illustrated that the test could be used to detect the presence of $A$. parasiticusonly in the tested samples (lane 2, 3, 4), while samples containing DNA solution of other species gave negative results (lane 5, 6, 7, $8,9,10,11,12,13)$. The specificity of the test was also demonstrated when $A$. parasiticus was detected in the mixture of the DNA solution of all tested species (lane 1, Figure 3). This indicated that the test was specific for detecting $A$. Parasiticus in the presence of other species.

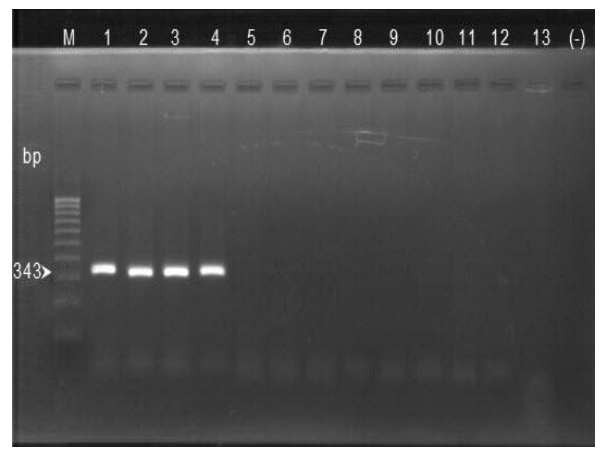

Figure 3. Gel electrophoresis of specificity testing. The target DNA band is at $343 \mathrm{bp}$. Lane 1: DNA mixture of selected species in table 1, lane 2: A. parasiticus VTCC-F-1130, lane 3: A. parasiticus VTCC-F-1132, lane 4: A. parasiticus VTCC-F-1159, lane 5: A. Flavus VTCC-F-160, lane 6: A. Flavus VTCC-F-898, lane 7: A. Flavus AF.IV26.1, lane 8: A. Flavus TN1, lane 9: A. oryzaeVTCC-F-910, lane 10: A. Oryzae VTCC-F-912, lane 11: A. niger ATCC-16404, lane 12: A. candidus, lane 13: P. aethiopicum, M: 100-bp DNA molecular weight ladder, (-): negative control 


\section{Sensitivity testing}

To assess the detection limit of the assay, two experiments were performed with a dilution series: $100-50-10-5-1-0.5-0.1-0.05-$ $0.01-0.005-0.001 \mathrm{ng} / \mu \mathrm{L}$ made with DNA extracted from Aspergillus parasiticus VTCC-F1132 and DNA mixture of these fungi (Table 1) with similar proportions of concentration.

The test was performed using the samples containing both DNA of Aspergillus parasiticus (VTCC-F-1132) only (Figure 4) and DNA mixture of all selected species (Table 1) at similar amount ratio (Figure 5). Figure 4 and Figure 5 showed a decrease in the intensity of bands from lane 1 to lane 11 , corresponding to $100 \mathrm{ng}$ to $0.001 \mathrm{ng}$ in each microliter of PCR reaction, respectively. However, bands expressed in Figure 5 appeared significantly smeared when great amount of DNA was used (lane 1, 2, 3 and 4). This phenomenon might be caused by high productivity of amplified products. The bands in lane 11 of both Figure 4 and Figure 5 were considerably faint and difficult to be observed by naked eyes under UV luminescence. Thus, the previous band (lane 10), corresponding to 0.005 ng of DNA in each microliter, was selected as the limit of detection (LOD), i.e. $\mathrm{LOD}=0.005$ $\mathrm{ng} / \mu \mathrm{L}$.

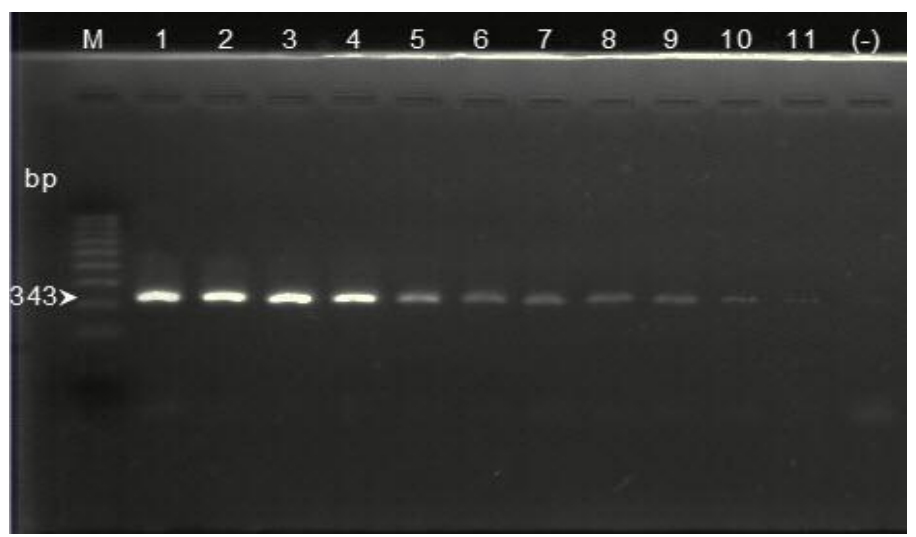

Figure 4. Gel electrophoresis of sensitivity testing on Aspergillus parasiticus VTCC-F-1132. The target DNA band is at 343bp. Lane 1: $100 \mathrm{ng}$, lane 2: $50 \mathrm{ng}$, lane 3: $10 \mathrm{ng}$, lane 4: $5 \mathrm{ng}$, lane 5: $1 \mathrm{ng}$, lane 6: 0.5, lane 7: 0.1, lane 8: 0.05, lane 9: 0.01, lane 10: 0.005, lane 11: 0.001. M: 100-bp DNA molecular weight ladder, (-): negative control.

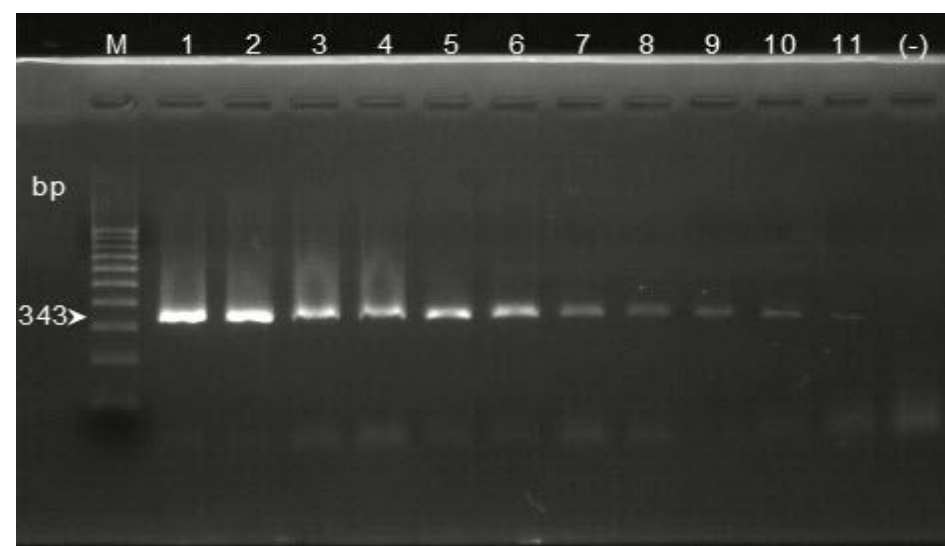

Figure 5. Gel electrophoresis of sensitivity testing on mixture of all selected species in Table 1. The target DNA band is at 343bp. Lane 1: $100 \mathrm{ng}$, lane 2: $50 \mathrm{ng}$, lane 3: $10 \mathrm{ng}$, lane 4: $5 \mathrm{ng}$, lane 5: $1 \mathrm{ng}$, lane 6: 0.5, lane 7: 0.1, lane 8: 0.05, lane 9: 0.01, lane 10: 0.005, lane 11: 0.001. M: 100-bp DNA molecular weight ladder, (-): negative control.

\section{Trang 48}




\section{DISCUSSION}

In this work, a highly specific method was developed to allow the detection of Aspergillus parasiticus, which would permit the prediction of whether aflatoxins type Gis present besides aflatoxins type B.

The sensitivity of PCR assay is dependent on the concentration of the target DNA input. The lowest detection limit of target DNA was estimated to be $0.005 \mathrm{ng} / \mu \mathrm{L}$ in comparison with $0.002 \mathrm{ng} / \mu \mathrm{L}$ in a similar study using real-time PCR method done by Sardinas [11]. However, with real-time PCR, the laboratories need to be equipped with expensive machine and costly chemicals. The validity of this assay was also confirmed when a mixture of target DNA and those of other related species with similar ratio were employed. A similar result to the one of pure target DNA was obtained.

The specificity of the assay was examined among a relatively diverse selection of strains and confirmed using a sample containing a DNA mixture of these strains. The use of the target sequence based on norB-cypA genes, which have shown to be an important factor in biosynthesis of aflatoxin type $\mathrm{G}$ in aflatoxin gene cluster, might enhance the specificity in the detection of A. parasiticus in comparison with other gene regions. Therefore, regarding its sensitivity, the PCR method would provide a better tool with high accuracy, rapidity and inexpensiveness for $A$. parasiticus as well as aflatoxins detection in comparison with the morphological methods.

However, to use this PCR assay for detection A.paraciticus in food it is necessary to perform more experiments to test the sensitivity of the test. Adding more controls such as internal control is necessary to avoid the fault results such as fault negative.

\section{CONCLUSION}

In this work, a PCR method using novel primers was successfully designed to detect the target genes norB-cypA, which is a part of the aflatoxin gene cluster. This PCR assay worked well at the annealing temperature of $62{ }^{\circ} \mathrm{C}$, providing a specific, accurate and sensitive tool to detect Aspergillus parasiticus among others Aspergillus species. The limit of detection in this PCR assay was $0.005 \mathrm{ng} / \mu \mathrm{L}$ of pure genomic DNA. This assay and the designed primer pair can be used for continue developing a PCR method which can apply for detection of A.paraciticus in food in the future.

ACKNOWLEDGEMENT: We would like to show gratitude to the Microbiology - GMO Testing Laboratory, Quality Assurance and Testing Centre 3 for providing the materials and facilities for this work. This research was funded by Vietnam National University Ho Chi Minh City under grant number B2013-28-02. 


\section{Phát triển một phản ứng $\mathrm{PCR}$ phát hiện Aspergillus parasiticus}

• Nguyễn Hũuu Nhiên

- Nguyễn Thị Mai Trâm

Trường Đại học Quốc tế, ĐHQG-HCM

- Nguyễn Thị Huệ

Trường Đai học Khoa học Tự Nhiên, ĐHQG-HCM

\section{TÓM TÁT}

Aspergillus parasiticus là một trong các loại nấm mốc tiết độc tố aflatoxin trong thức ăn. Loại nấm mốc này có thể tiết ra aflatoxin $B$ hay $G$ dẫn tới bệnh nghiêm trọng ở người. Aflatoxin là một loại tác nhân gây ung thư. Người ăn phải thức ăn chứa dù chứa lượng nhỏ aflatoxin trong một khoảng thời gian dài có thể mắc phải ung thư do aflatoxin tích tụ. Do vậy, việc nhận biết aflatoxin và nhân tố tiết aflatoxin trong thực phẩm là cần thiết để tăng chất lượng cuộc sống bằng cách giảm nguy cơ mắc bệnh. Gần đây, phương pháp thông dụng để nhận biết $A$. parasiticus là phương pháp quan sát hình thái, tuy nhiên phương pháp này vẫn còn nhiều hạn chế. Đề tài này phát triển một phản ứng $P C R$ truyền thống nhằm phát hiện $A$. parasiticus trong thực phẩm vượt qua những hạn chế của phương pháp hình thái hiện đang sử dụng. Một cặp mồi riêng biệt được thiết kế dựa trên genes norB-cypA đã được tối ưu

\section{REFERENCES}

[1]. C. Beck-Sague, W.R. Jarvis, Secular trends in the epidemiology of nosocomial fungal infections in the United States, 1980-1990. National Nosocomial Infections Surveillance System, J Infect Dis, 167, 5, 1247-51 (1993).

[2]. JECFA, Evaluation of certain food addictives and contaminants. Forty-sixth Report of the Joint FAO/WHO Expert Committee on Food hoá cho kết quả khuếch đại nhiều nhất ở $62{ }^{\circ} \mathrm{C}$. Độ nhạy của phương pháp PCR này được xác định là có thể phát hiện DNA nấm mốc A. paraciticus ở nồng độ $0.005 \mathrm{ng} / \mu \mathrm{L}$. Quy trình tách DNA cũng được tối ưu hoá để đảm bảo sự thành công cho phản ứng $P C R$ bằng cách sử dụng ly giải $S D S$, cát và sốc nhiệt. Quy trình từ tách DNA đến PCR được phát triển có thể sẽ được ứng dụng để phát hiện A. parasiticus trong thực phẩm ở các giai đọạn khác nhau, tạo công cụ hữu dụng trong việc phát hiện aflatoxins ở giai đoạn đầu và kiểm soát tốt các giai đoạn sản xuất thực phẩm. Thành công của nghiên cứu này là thiết kế được cặp mồi và phản ứng $P C R$ đặc hiệu có thể phân biệt $A$. parasiticus trong số các loài Aspergillus khác. Phản ưng $P C R$ này có thể tiếp tục phát triển để có thể ứng dụng trong phát hiện $A$. parasiticus trong thực phẩm trong tương lai.

Additives 1996, in WHO Technical Report Series, WHO (1997).

[3]. IARC, International Agency for Reaearch on Cancer: Monographs on the evaluation of carcinogenic risks to huaman, IARC, Lyon, France, 257-263 (1993).

[4]. J.W. Bennett, et al., Sip-sizing behaviors in natural drinking conditions compared to

\section{Trang 50}


instructed experimental conditions, Dysphagia, 24, 2, 152-8 (2009).

[5]. Y.C. Lin, J.C. Ayres, P.E. Koehler, Influence of temperature cycling on the production of aflatoxins $\mathrm{B} 1$ and $\mathrm{G} 1$ by Aspergillus parasiticus, Appl Environ Microbiol, 40, 2, 333-6 (1980).

[6]. P.S. Yan, et al., Cyclo(L-leucyl-L-prolyl) produced by Achromobacter xylosoxidans inhibits aflatoxin production by Aspergillus parasiticus, Appl Environ Microbiol, 70(12), 7466-73 (2004).

[7]. K.A. Hamed, W.T. Sheir, B.W. Horn, M.A. Weaver, Cultural methods for aflatoxin detection, Journal of Toxicology. Toxin Reviews, 23(2-3), 295-315 (2004).

[8]. M. Rashid, S. Khalil, N. Ayub, W. Ahmed, A.G. Khan, Categorization of Aspergillus flavus and Aspergillus parasiticus isolates of stored wheat grains in to aflatoxinogenics and non-aflatoxinogenics, Pak. J. Bot., 40(5), 2177-2192 (2008).

[9]. B. Scherm, et al., Detection of transcripts of the aflatoxin genes aflD, aflO, and aflP by reverse transcription-polymerase chain reaction allows differentiation of aflatoxinproducing and non-producing isolates of Aspergillus flavus and Aspergillus parasiticus, Int J Food Microbiol, 98(2), 20110 (2005).

[10]. R.S. Chen, et al., Polymerase chain reactionmediated characterization of molds belonging to the Aspergillus flavus group and detection of Aspergillus parasiticus in peanut kernels by a multiplex polymerase chain reaction, $J$ Food Prot, 65(5), 840-4 (2002).

[11]. N. Sardinas, et al., Specific detection of Aspergillus parasiticus in wheat flour using a highly sensitive PCR assay, Food Addit Contam Part A Chem Anal Control Expo Risk Assess, 27(6), 853-8 (2010).
[12]. N. Sardinas, et al., Specific detection and quantification of Aspergillus flavus and Aspergillus parasiticus in wheat flour by SYBR(R) Green quantitative PCR, Int J Food Microbiol, (2010).

[13]. J. Yu, D. Bhatnagar, T.E. Cleveland, Completed sequence of aflatoxin pathway gene cluster in Aspergillus parasiticus, FEBS Lett, 564(1-2), 126-30 (2004).

[14]. J. Yu, et al., Comparative mapping of aflatoxin pathway gene clusters in Aspergillus parasiticus and Aspergillus flavus, Appl Environ Microbiol, 61(6), 2365-71 (1995).

[15].J. Yu, et al., Clustered pathway genes in aflatoxin biosynthesis, Appl Environ Microbiol, 70(3), 1253-62 (2004).

[16]. L. Harvey, B. McNeil, Biotechnology Handbooks, 7, 141-176 (1994).

[17]. J.W. Rippon, Medical Mycology, 3 ed. The pathogenic fungi and the pathogenic actinomycestes, Philadelphia: Saunders (1988).

[18]. J.I. Pitt, A.D. Hocking, Fungi and food spoilage. 3rd ed., Dordrecht ; New York: Springer, 519 (2009).

[19]. G.A. Plaza, R. Upchurch, R.L. Brigmom, W.B. Whitman, Rapid DNA extraction for screening soil filamentous fungi using PCR amplification, Polish Journal of Environmental Studies, 13(3), 315-318 (2003).

[20]. K.C. Ehrlich, et al., Aflatoxin biosynthesis cluster gene cypA is required for $\mathrm{G}$ aflatoxin formation, Appl Environ Microbiol, 70(11), 6518-24 (2004).

[21]. K.C. Ehrlich, J. Yu, P.J. Cotty, Aflatoxin biosynthesis gene clusters and flanking regions, J Appl Microbiol, 99(3), 518-27 (2005). 